\title{
BEBERAPA FAKTOR YANG BERDAMPAK PADA PERBEDAAN AUDIT DELAY (STUDI EMPIRIS PADA PERUSAHAAN-PERUSAHAAN KEUANGAN YANG TERDAFTAR DI BEJ)
}

\author{
Jeane Deart Meity Prabandari \\ Rustiana \\ Universitas Atma Jaya Yogyakarta
}

\begin{abstract}
This study examines the factors are impact on differences of audit delay in the financing firms that listed at Jakarta Stock Exchange (JSE). These factors are total revenue, debt to assets ratio, gains or losses, audit opinion, and characteristic's of accounting firms. Audit delay is measured as the length from the date of the project year-end to the date audit submits the annual report to BAPEPAM. Four hypotheses were tested by independent t-test or ANOVA. The study based on a sample of 111 the financial companies listed at JSE in year ended 2002 until 2004. There were differences of audit delay in total revenue and profit or loss announcement. But, no differences of audit delay in audit opinion and characteristic's accounting firms.
\end{abstract}

Keyword: audit delay, total revenue, debt to seets ratio, , audit opinion and characteristi's accounting firms

\section{PENDAHULUAN}

Penelitian mengenai audit delay telah banyak dilakukan baik didalam negeri (Naim, 1998; Halim, 1999; Yuliana dan Ardiati, 2004; dan Wirakusuma, 2004) maupun di luar negri (Lawrence dan Bryan, 1998; OwusuAnsah, 2000; dan Imam et.al, 2001). Kebanyakan penelitian-penelitian tersebut menguji pengaruh bermacam variabel, seperti ukuran perusahaan, jenis industri, profitabilitas, solvabilitas, internal audit, reputasi auditor, dan opini auditor terhadap audit delay. Pada penelitian ini, penulis mencoba menganalisis audit delay dengan menggunakan pendekatan uji beda atas faktor-faktor seperti total revenue, debt to asset ratio, audit opinion, dan karakteristik KAP yang berdampak pada perbedaan audit delay.

Agar berguna dalam pembuatan keputusan bisnis, informasi akuntansi yang tercantum dalam laporan keuangan harus reliabel, relevan, dan tepat waktu. Salah satu indikator utama yang menentukan persepsi ketepatan waktu/timeliness oleh pengguna laporan keuangan auditan adalah lamanya waktu laporan keuangan akhir tahun fiskal dengan penerbitan pengumuman laba (earnings pronouncement). Menurut Givoly dan Palmon (1992) lamanya audit merupakan "single most important of the timeliness of earnings announcement". Ini mencerminkan bahwa hal yang paling penting adalah penyajian pengumuman laba yang tepat waktu kepada publik, sehingga diharapkan perusahaan tidak menunda penyajian laporan keuangan. Penundaan ini dapat menyebabkan manfaat informasi menjadi kurang relevan bagi pengguna informasi keuangan terutama investor dalam membuat keputusan investasi.

Aspek timeliness merupakan fungsi lamanya jam kerja audit yang dibutuhkan auditor dan dipengaruhi oleh sejumlah faktor seperti jenis pekerjaan audit yang dilakukan, jumlah personil audit yang diberi penugasan, jumlah waktu kerja, dan jumlah jam kerja lembur (Lawrence dan Bryan, 1998). Selanjutnya Lawrence dan Bryan mengutip temuan penelitian Ashton dan Elliot (1987) mengenai audit delay yang akan semakin panjang untuk perusahaanperusahaan yang memiliki aset yang besar, kondisi keuangan yang buruk atau kesibukan yang padat menjelang 
akhir tahun buku. Dyer dan Hugh (1975 dalam Lawrence dan Bryan, 1998) menyatakan penyebab lamanya audit delay juga dipengaruhi oleh faktor ketidaksepakatan antara manajemen klien dengan auditor, masalah-masalah dalam akuntansi normal dan masalah auditing .

Salah satu indikator utama yang menentukan persepsi aspek timeliness oleh pengguna informasi audit adalah lamanya waktu tanggal laporan keuangan akhir tahun sampai dengan tanggal penyerahan laporan audit ke lembaga regulasi yakni dalam hal ini BAPEPAM. Laporan keuangan yang sudah diaudit akan digunakan oleh pihakpihak yang berkepentingan seperti pemegang saham, kreditur, pemerintah maupun masyarakat untuk mengetahui kinerja perusahaan yang berguna dalam pengambilan keputusan ekonomi. Laporan keuangan akan tepat guna apabila laporan keuangan tersebut disajikan dengan akurat dan tepat waktu. Apabila jarak waktu antara akhir periode akuntansi dengan tanggal publikasi laporan keuangan auditannya lebih singkat maka laporan tersebut akan memberikan keuntungan/manfaat dalam mengambil keputusan bagi para pemakai laporan keuangan. Namun, disisi lain proses auditing membutuhkan banyak waktu dan sifat kehati-hatian sehingga laporan keuangan maupun pengumuman laba/rugi suatu perusahaan yang diaudit dapat tertunda.

Beberapa peneliti menemukan ada hubungan antara ketepatan informasi dengan berita bagus/good news atau berita buruk/bad news (Lawrence dan Bryan, 1998). Sebagai contoh, Chambers dan Penman (1984 dalam Lawrence dan Bryan, 1998) menemukan bahwa ada hubungan antara keterlambatan pengumuman dengan bad news. Auditor lebih membutuhkan waktu yang relatif lama untuk mencari sejumlah hal-hal yang membuktikan/ evidential matter sehingga terjadi peningkatan audit delay. Dalam Standar Umum ketiga menyatakan bahwa audit harus dilaksanakan dengan penuh kecermatan dan ketelitian. Demikian juga dalam Standar Pekerjaan Lapangan pertama dan ketiga menyatakan bahwa audit harus dilaksanakan dengan perencanaan yang matang dan pengumpulan alat-alat pembuktian yang cukup memadai. Dengan adanya standar ini, proses pengauditan membutuhkan waktu yang relatif lama, akibatnya akuntan publik dapat menunda untuk mempublikasikan laporan audit atau laporan keuangan auditannya. Kondisi ini sering disebut dengan audit delay. Audit Delay didefinisikan sebagai lamanya waktu penyelesaian audit yang diukur dari tanggal penutupan tahun buku hingga tanggal diterbitkannya laporan audit (Lawrence dan Bryan, 1998).

Ketepatan waktu penyajian laporan keuangan ke publik adalah sebagai sinyal dari perusahaan yang menunnjukkan adanya informasi yang bermanfaat untuk memenuhi kebutuhan investor dalam membuat keputusan bisnis. Informasi yang terkandung dalam laporan keuangan akan kurang bermanfaat apabila tenggang waktu antara akhir periode akuntansi dan waktu publikasi laporan keuangan semakin jauh. Hal ini telah ditegaskan oleh Abdullah (1996 dalam Wirakusuma, 2004) yang menyatakan bahwa semakin panjang periode antara akhir periode akuntansi dengan waktu publikasi laporan keuangan, semakin tinggi kemungkinan informasi dibocorkan pada pihak yang berkepentingan bahkan dapat menimbulkan terjadinya insider trading dan rumor-rumor lain di bursa saham. Selain itu juga dapat menyebabkan, informasi yang ada sudah tidak up-to-date sehingga berkurang manfaatnya bagi pengguna informasi tersebut. Lamanya waktu penyelesaian audit (audit delay) akan dapat mempengaruhi ketepatan waktu publikasi informasi keuangan auditan, disamping faktor-faktor spesifik perusahaan itu sendiri (Givoly dan Palmon, 1992; Asthon et. al 1997) sehingga berdampak pada reaksi pasar terhadap keterlambatan informasi tersebut dan mempengaruhi tingkat ketidakpastian keputusan yang didasarkan pada informasi yang dipublikasikan. Penelitian Chamber dan Penman (1984 dalam Lawrence dan Bryan, 1998) menunjukkan bahwa pengumuman laba yang terlambat menyebabkan abnormal returns sedangkan pengumuman laba yang lebih cepat menyebabkan hal sebaliknya.

\section{TINJAUAN LITERATUR DAN PENGEMBANGAN HIPOTESIS}

\subsection{Tinjauan Litelatur}

Penyampaian dan publikasian laporan keuangan auditan kepada regulator maupun kepada publikmerupakan suatu keharusan bagi emiten yang diatur dalam Keputusan Bapepam Nomor 8/PM/1996. Keputusan ini berisi aturan yang mewajibkan emitan menyampaikan laporan keuangan berkala (akhir tahunan dan tengah tahunan) 


\section{Beberapa Faktor yang Berdampak pada Perbedaan Audit Delay}

(Jeane Deart Meity Prabandari dan Rustiana)

yang disusun berdasarkan Standar Akuntansi Keuangan kepada Bapepam selambat-lambatnya 120 hari sejak tanggal akhir tahun buku perusahaan, dan wajib diumumkan ke publik paling tidak melalui dua surat khabar harian berbahasa Indonesia. Ketentuan lamanya waktu yang dibutuhkan akuntan publik untuk menyelesaikan proses pengauditan hingga penyajian opini atas laporan keuangan auditan, merupakan faktor utama yang mempengaruhi porses penyajiannya ke publik, dibawah ketentuan batas waktu yang diharuskan oleh Bapepam sebagai regulator pasar modal (Wirakusuma, 2004).

Menurut Owusu-Ansah (2000), ketepatan waktu laporan keuangan dikategorikan menjadi dua yakni yang berhubungan dengan dampak ketepatan waktu laporan keuangan terhadap return saham (Chambers dan Penman, 1994) dan yang berhubungan dengan kelambatan (lag) pelaporan serta faktor-faktor yang mempengaruhi pelaku pelaporan tepat waktu (Dyer dan McHugh, 1975 dalam Wirakusuma, 2004)

Menurut McLelland and Giroux (dalam Yuliana dan Ardiati, 2004) ada 3 alasan yang mempengaruhi ketepatan waktu pelaporan keuangan. Pertama, kebutuhan dari pihak-pihak yang menggunakan laporan keuangan yang mengandalkan informasi yang terdapat dalam laporan auditor untuk membuat keputusan, antara lain pihak penjamin obligasi dan agen penilai obligasi yang di Indonesia dipegang oleh Bapepam. Sedangkan investor lebih mengacu pada rating obligasi perusahaan-perusahaan tersebut. Audit delay dapat mengakibatkan tingkat resiko yang lebih tinggi, missed opportunities dan asimetri informasi yang semakin luas. Kedua, efisiensi audit dapat ditingkatkan apabila memiliki pemahaman yang lebih tentang ketepatan waktu laporan audit. Efisiensi audit tercapai bila semakin sedikitnya input audit diperlukan untuk mencapai output tertentu. Ketiga, ketepatan waktu audit merupakan sinyal kompetensi manajemen keuangan yang efektif.

\subsection{Hubungan ukuran perusahaan dengan audit delay}

Faktor ukuran perusahaan merupakan salah satu faktor yang sering diteliti pada penelitian sebelumnya. Givoly dan Palmon (1982) dalam penelitiannya menemukan adanya hubungan mutivariat anatra ukuran perusahaan, kompleksitas perusahaan dan kualitas pengendalian internal dengan audit delay. Namun, hanya ratio of inventory to total asset yang signifikan. Ukuran perusahaan merupakan fungsi dari kecepatan pelaporan keuangan karena semakin besar suatu perusahaan maka akan melaporkan semakin cepat karena perusahaan memiliki lebih banyak sumber informasi. Menurut Courtis di New Zealand (1976), penelitian Gilling (1977), penelitian Davies dan Whitterd di Australia (1980), dan lain sebagainya (dalam Imam, Zahir dan Sadia, 2001) menunjukkan bahwa audit delay memiliki hubungan negatif dengan ukuran perusahaan yang menggunakan proksi total aktiva. Artinya bahwa semakin besar aset perusahaan maka semakin pendek audit delay. Penyebabnya adalah pertama, perusahaanperusahaan go public atau perusahaan besar mempunyai sistem pengendalian internal yang baik sehingga dapat mengurangi tingkat kesalahan dalam penyajian laporan keuangan perusahaan sehingga memudahkan auditor dalam melakukan pengauditan laporan keuangan. Lemahnya pengendalian internal klien memberikan dampak audit delay yang semakin panjang karena auditor membutuhkan sejumlah waktu untuk mencari evidential matter yang lebih lengkap dan kompleks untuk mendukung opininya.

Kedua, perusahaan-perusahaan besar mempunyai sumber daya keuangan untuk membayar audit fee yang lebih besar guna mendapatkan pelayanan audit yang lebih cepat. Dan yang ketiga, perusahaan-perusahaan besar cenderung mendapat tekanan dari pihak eksternal yang tinggi terhadap kinerja keuangan perusahaan, sehingga manajemen akan berusaha untuk mempublikasikan laporan audit dan laporan keuangan auditan lebih tepat waktu (Ahmad dan Kamarudin, 2002 dalam Yuliana dan Ardiati, 2004). Wirakusuma (2004) mengutip pernyataan Dyer dan Hugh (1975) yang menyatakan bahwa manajemen perusahaan besar, memiliki dorongan untuk mengurangi masalah audit delay dan penundaan laporan keuangan. Ini disebabkan karena perusahaan besar senantiasa diawasi secara ketat oleh para investor, asosiasi perdagangan, dan oleh agen regulator. Disamping itu perusahaan besar menghadapi tekanan yang kuat untuk menyampaikan laporan keuangan lebih cepat dibandingkan dengan perusahaan kecil.

Pada penelitian Ashton dan Elliot (1987) ukuran perusahaan diukur dengan menggunakan total revenue yang hasilnya menunjukkan bahwa perusahaan tidak memiliki hubungan yang signifikan dengan audit delay. 
Penelitian tersebut juga mengindikasikan bahwa audit delay lebih lama untuk perusahaan-perusahan besar yang tidak Go Public sedangkan audit delay perusahaan-perusahaan Go Public lebih singkat. Ashton dan Elliot (1987) mengklasifikasikan audit delay dilihat dari segi klasifikasi industri kedalam kelompoj finansial dan non finansial. Hasil penelitian ini adalah bahwa industri yang bergerak dalam bidang finansial mengalami audit delay yang lebih singkat dibandingkan dengan jenis industri lainnya. Industri finansial lebih singkat masa audit delay, karena industri finansial relatif sedikit atau tidak memiliki akun persediaan. Dalam penelitian ini ukuran perusahaan menggunakan proksi total revenue seperti yang telah digunakan oleh Halim (1999), karena lebih mencerminkan kemampuan perusahaan dalam menjalankan aktifitas operasional bisnis, sehingga dengan demikian hipotesis penelitian dirumuskan, sebagai berikut:

\section{$\mathrm{H}_{1}$ : Ada perbedaan audit delay ditinjau dari total revenue.}

\subsection{Hubungan debt to total asset dengan audit delay}

Menurut Courtis (1976, dalam Halim 1999), dan Ashton (1987) menemukan bahwa perusahaan-perusahaan finansial mengalami audit delay yang lebih pendek dibandingkan dengan perusahaan-perusahaan dalam jenis industri lain. Hal ini disebabkan perusahaan-perusahaan finansial tidak memiliki saldo persediaan yang cukup signifikan sehingga audit yang dilakukan cenderung tidak memerlukan waktu yang relatif lama. Aset yang dimiliki oleh perusahaan-perusahaan finansial berupa nilai moneter sehingga lebih mudah diukur bila dibandingkan dengan asset yang berbentuk fisik seperti persediaan, aktiva tetap, dan aktiva tak berwujud.

Debt to assets ratio pertama kali digunakan dalam penelitian audit delay oleh Carslaw dan Kaplan (1989 dalam Yuliana dan Ardiati, 2004). Hasil penelitian menemukan adanya hubungan yang positif antara debt to asset ratio dengan audit delay. Alasan yang dapat mendukung hubungan antara Debt to assets ratio adalah pertama, bahwa debt to assets ratio mengindikasikan kesehatan dari perusahaan. Proposi Debt to assets ratio yang tinggi akan meningkatkan kegagalan perusahaan sehingga auditor akan meningkatkan perhatiaan bahwa ada kemungkinan laporan keuangan kurang dapat dipercaya. Sebagai contoh, kesehatan perusahaan yang rendah akan meningkatkan kemungkinan terjadinya kecurangan manajemen atau ketidaksengajaan untuk mengurangi karyawan. Sebagai konsekuensinya, auditor akan meningkatkan lamanya waktu dalam periode audit. Kedua, mengaudit hutang memerlukan waktu yang lebih lama dibandingkan dengan mengaudit modal. Biasanya mengaudit hutang lebih melibatkan banyak staf dan lebih rumit dibandingkan dengan mengaudit modal (Carslaw dan Kaplan, 1991). Debt to assets ratio yang tinggi memberikan sinyal bahwa perusahaan sedang dalam kesulitan keuangan. Biasanya perusahaan akan mengurangi resiko dengan memundurkan publikasi laporan keuangannya dan mengulur waktu dalam pekerjaan auditnya. Ini memberikan sinyal ke pasar bahwa perusahaan dalam tingkat resiko yang tinggi. Dengan demikian, auditor akan mengaudit laporan keuangan perusahaan dengan lebih seksama dan membutuhkan waktu yang raltif lama sehingga dapat meningkatkan audit delay. Dengan demikian hipotesis penelitian dirumuskan sebagai berikut:

$\mathrm{H}_{2}$ : Ada perbedaan audit delay ditinjau dari Debt to Assets Ratio.

\subsection{Hubungan pengumuman laba/rugi dengan audit delay}

Hossain dan Taylor (1998) memaparkan penelitian Courtis (1976) di New Zealand yang menunjukkan ada hubungan yang positif antara audit delay dengan pengumuman rugi/laba. Namun hasil penelitian mereka, memberikan bukti bahwa kedua variabel tersebut menunjukkan hubungan yang negatif. Menurut Ashton (1987) Net income suatu perusahaan akan mengindikasikan "berita baik" atau "berita buruk" selama tahun berjalan. Perusahaan yang mengumumkan rugi untuk periode tersebut audit delay akan lebih panjang. Lawrence (1983 dalam Wirakusuma, 2004) menemukan bukti bahwa perusahaan-perusahaan di Amerika yang mengalami finansial distress telah menunda penerbitan laporan keuangan mereka. Menurut Carslaw dan Kaplan(1991 dalam Lawrence dan Bryan, 1998) apabila perusahaan rugi maka perusahaan akan meminta auditornya untuk menjadualkan 
pengauditan lebih lambat dari biasanya sehingga menunda untuk mengumumkan "bad news" kepada publik. Auditor akan bertindak lebih berhati-hati dan cermat selama proses audit dalam memberikan jawaban apakah peningkatan kerugian yang dialami oleh perusahaan diakibatkan oleh kegagalan atau disebabkan oleh kecurangan manajemen. Sementara pada perusahaan yang memiliki profitabilitas tinggi cenderung mengharapkan penyelesaian audit secepat mungkin sehingga mampu mengumumkan laporan keuangan auditan ke publik lebih awal. Wirakusuma (2004) mengutip temuan Dye dan Sridhar (1995) bahwa perusahaan yang memiliki good news akan melaporkan lebih tepat waktu dibandingkan dengan perusahaan yang operasionalnya gagal (bad news).

Penelitian Halim (1999), membuktikan audit delay dipengaruhi secara positif oleh adanya pengumuman rugi/laba usaha. Perusahaan yang mengumumkan rugi cenderung mengalami audit delay yang lama dibandingkan dengan perusahaan yang mengumumkan laba. Menurut Na'im (1998) tingkat profitabilitas yang rendah memacu kemunduran publikasi laporan keuangan. Dengan demikian, hipotesis penelitian dirumuskan sebagai berikut:

\section{$\mathrm{H}_{3}$ : Ada perbedaan audit delay ditinjau dari aspek rugi/laba.}

\subsection{Hubungan audit opinion dengan audit delay}

Penelitian Carslaw dan Kaplan (1991) yang mengkonfirmasi penelitian Whitred (1980 dalam Lawrene dan Bryan, 1998) menemukan adanya hubungan positif antara opini audit dengan audit delay. Pada perusahaan yang menerima jenis pendapat qualified opinion akan menunjukkan audit delay yang lebih panjang dibandingkan dengan perusahaan angmeneriima pendapat unqualifed opinion. Menurut Elliott (1982 dalam Halim, 1999), audit delay yang relatif lama pada perusahaan yang menerima qualified opinion, disebabkan karena proses pemberian opini auditor melibatkan negoisasi dengan klien, konsultasi dengan partner audit yang lebih senior atau staf teknis lainnya dan perluasan lingkup audit. Hasil penelitian ini konsisten dengan observasi Simunic (1980 dalam Halim, 1999) yang menemukan bahwa fee audit akan semakin besar apabila pemberian pendapat menunjukkan qualified opinion. Tetapi menurut Na'im (1998) variabel ini di Indonesia menunjukkan hasil yang kurang memuaskan dimana pendapat akuntan publik tidak berpengaruh terhadap ketidaktepatan pelaporan keuangan. Didasarkan pada penjelasan tersebut, hipotesis penelitian dirumuskan sebagai berikut:

$\mathrm{H}_{4}$ : Laporan keuangan yang diberi Qualified opinion lebih panjang waktu audit delaynya dibandingkan dengan Unqualified opinion.

\subsection{Hubungan ukuran KAP dengan audit delay}

Penelitian yang dilakukan oleh Gilling (1977) dalam Hossain and Taylor (1998) yang menguji secara empiris karakteristik kantor akuntan publik (KAP) dengan audit delay. Ada kecenderungan bahwa KAP Big Five lebih cepat menyelesaikan tugas audit yang mereka terima dibandingkan dengan KAP non Big Five dikarenakan reputasi yang harus mereka jaga (Hossain dan Taylor, 1998). Apabila reputasi auditor tidak dijaga, maka ada kemungkinan mereka akan kehilangan pekerjaan penugasan audit dari klien untuk tahun-tahun berikutnya sebab dinilai kurang kompeten. Penelitian yang dilakukan oleh Wooten yang memaparkan teori DeAngelo (1981 dalam Halim, 1999) menunjukkan bahwa KAP besar (the Big Five) cenderung menyajikan audit yang lebih baik dibandingkan dengan KAP kecil (non the Big Five), karena mereka memiliki nama baik yang dipertaruhkan. Selain itu, KAP besar lebih banyak mengeluarkan pendapat going concern daripada KAP kecil (Yuliana dan Ardiati, 2004). Hal tersebut mengindikasikan bahwa KAP besar lebih menginginkan untuk mengambil sikap yang tepat dalam mengeluarkan pendapat sesuai dan memiliki kemampuan teknis untuk mendeteksi going concern perusahaan sehingga dapat lebih menarik klien yang lebih banyak.

Semenjak adanya kasus Enron, KAP besar (the Big Five) menjadi the Big Four. Adapun kategori Kantor Akuntan Publik yang berafilasi dengan The Big Four di Indonesia, yaitu:

1. KAP Price Waterhouse Coopers, yang berafiliasi dengan KAP Drs. Hadi Sutanto \& Rekan, Haryanto Sahari \& Rekan. 
2. KAP KPMG (Klynveld Peat Marwick Goerdeler), yang bekerja sama dengan KAP Sidharta-Sidharta \& Widjaja.

3. KAP Ernst \& Young, yang bekerja sama dengan KAP Prasetio, Drs. Sarwoko \& Sanjaja.

4. KAP Deloitte Touche Thomatsu, yang bekerja sama dengan KAP Hans Tuanakota \& Mustofa.

KAP Big Four umumnya memiliki sumber daya yang lebih besar(kompetensi, keahlian, dan kemampuan auditot; fasilitas; sistem dan prosedur pengauditan yang digunakan, dll) dibandingkan dengan KAP Non Big Four sehingga KAP Big Four akan dapat menyelesaikan pekerjaan audit dengan lebih efektif dan efisien. Hal tersebut menimbulkan dugaan bahwa perusahaan yang diaudit oleh KAP yang termasuk the Big Four cenderung lebih cepat menyelesaikan tugas audit bila dibandingkan dengan KAP Non Big Four. Sehingga dengan demikian hipotesis penelitian dirumuskan sebagai berikut:

H5: Laporan keuangan yang diaudit oleh Kantor Akuntan Publik Big Four waktu audit delay lebih singkat dibandingkan dengan Kantor Akuntan Publik non Big Four.

\section{METODA PENELITIAN}

\subsection{Penentuan Sampel}

Sampel untuk penelitian ini adalah semua perusahaan dalam industri keuangan yang terdaftar di Bursa Efek Jakarta (BEJ) periode tahun 2002 sampai 2004, dengan pertimbangan bahwa industri keuangan/finansial dijadikan salah satu alternatif bagi masyarakat untuk berinvestasi selain berinvestasi di pasar modal ataupun danareksa.

Sampel dipilih dengan cara purposive sampling, dengan menggunakan kriteria berikut:

a. Perusahaan tidak melakukan Initial Public Offering (IPO) dari tahun 2002 sampai dengan tahun 2004.

b. Perusahaan sampel menerbitkan laporan keuangan auditan selama tiga tahun berturut-turut, yaitu dari tahun 2002 sampai dengan tahun 2004.

\subsection{Pengumpulan Data}

Data sekunder diambil dari laporan keuangan dan laporan audit masing-masing emiten yang memuat opini akuntan publik yang dipublikasikan dari tahun 2002 sampai tahun 2004. Data diperoleh dari Galeri Efek Rifan Financindo cabang Fakultas Ekonomi Universitas Atma Jaya Yogyakarta dan dilengkapi oleh Indonesian Capital Market Directory (ICMD).

\subsection{Definisi operasional variabel dan pengukurannya}

a. Audit Delay (AUDELAY) adalah lamanya hari yang dibutuhkan auditor untuk menyelesaikan pekerjaan audit, yang diukur dari tanggal penutupan tahun buku hingga tanggal diterbitkannya laporan audit (Lawrence dan Bryan, 1998)

b. Ukuran perusahaan (TOREV) ukuran perusahaan diproksikan dengan variabel total revenue sesuai dengan penelitian Halim (1999). Pengukuran dengan menggunakan total revenue memiliki kelebihan dibandingkan apabila menggunakan total asset. Pada penelitian ini total revenue diukur cara nilai total revenue tertinggi dikurangi nilai total revenue terendah dibagi 3. Kategorinya sebagai berikut : 
Tabel 1

Kategori Total Revenue

\begin{tabular}{clrrr}
\hline Variabel & & \multicolumn{3}{c}{ Kategori ( dalam jutaan Rupiah) } \\
\hline Ukuran perusahaan & Tinggi & $10,820,158.34$ & s/d & $16,230,211.00$ \\
& Sedang & $5,410,105.68$ & s/d & $10,820,158.33$ \\
& Rendah & 53.00 & s/d & $5,410,105.67$ \\
\hline
\end{tabular}

c. Debt to Assets Ratio (DAR) yang diukur dari perbandingan hutang dengan asset pada akhir tahun akuntansi. Pengukuran variabel ini dengan cara nilai rasio Debt to Assets Ratio yang tertinggi dikurangi dengan nilai rasio Debt to Assets Ratio yang terendah dibagi 2. Kategori dari Debt to Assets Ratio, sebagai berikut :

Tabel 2

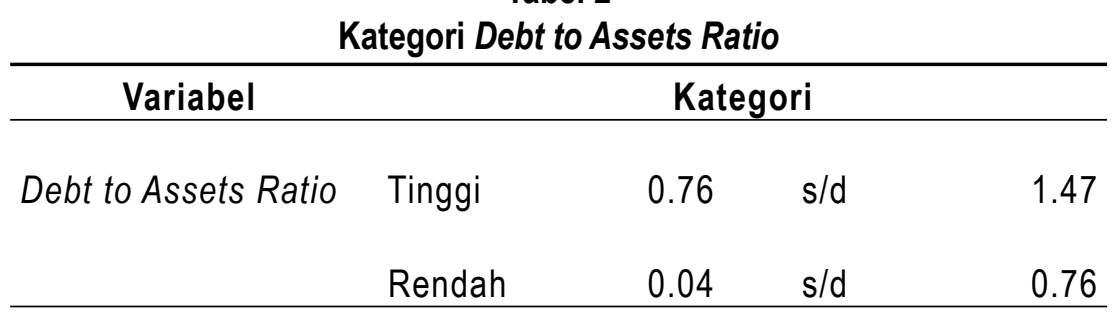

d. Rugi/Laba Perusahaan (LOSS / PROFIT) ini sudah diteliti oleh Halim (1999. Pengukuran variabel ini dengan cara memberi kode untuk perusahaan yang mengumumkan rugi diberi kode '1' sedangkan apabila perusahaan mengumumkan laba diberi kode ' 0 '.

e. Karakteristik Kantor Akuntan Publik (BFOUR). Pengukuran variabel ini dengan cara memberi kode ' 1 ' untuk KAP the Big Four, sedangkan KAP non big four diberi kode 'O'.

\section{Analisis Data dan Pembahasan}

Dari periode pengamatan mulai dari tahun 2002 sampai dengan 2004 terdapat 62 perusahaan finansial yang listing di Bursa Efek Jakarta. Pada periode analisis tersebut terdapat 11 perusahaan yang melakukan IPO sehingga harus dikeluarkan dari daftar sampel. Kemudian perusahaan yang datanya tidak lengkap sebanyak 14 perusahaan. Pada akhirnya hanya ada 37 perusahaan yang menghasilkan 111 sampel pengamatan untuk dianalisis lebih lanjut.

\section{Tabel 3}

Sampel Penelitian

\begin{tabular}{lc}
\hline \multicolumn{1}{c}{ Keterangan } & Jumlah Penelitian \\
\hline Perusahaan Finansial yang terdaftar di BEJ sampai Desember 2004 & 62 \\
Perusahaan yang melakukan IPO tahun 2002 - 2004 & $(11)$ \\
Perusahaan yang datanya tidak lengkap & $(14)$ \\
Jumlah sampel yang digunakan dalam penelitian & 37 \\
\hline
\end{tabular}

\subsection{Statistik Deskriptif} 22,28 hari.

Pada tabel 4 dapat dibaca bahwa audit delay pada penelitian ini rata-rata 71,62 hari dengan standar deviasi 
Tabel 4

Statistik Deskriptif

\begin{tabular}{lcccccc}
\hline & $\mathbf{n}$ & Range & Min & Max & Mean & Std. Deviation \\
\hline Audelay ( dalam hari) & 111 & 133 & 9 & 142 & 71.62 & 22.28. \\
$\begin{array}{l}\text { Ukuran Perusahaan } \\
\text { (dalam jutaan Rp) }\end{array}$ & 111 & 16.230 .158 & 53 & 16.230 .211 & 1.666 .871 & 3.481 .718 \\
Debt to Assets Ratio & 111 & 1.43 & .04 & 1.47 & .6792 & .29686 \\
\hline
\end{tabular}

Hasil lamanya rata-rata audit delay pada penelitian ini lebih pendek bila dibandingkan dengan penelitian Halim (1999) yang mendapatkan hasil audit delay di Indonesia pada tahun 1993-1997 selama 84,45 hari; dan lebih panjang bila dibandingkan dengan penelitian Yuliana dan Ardiati (2004) yang menemukan rata-rata audit delay sebanyak 65,77 hari.

Bila dibandingkan dengan audit delay dari para peneliti di luar Indonesia, audit delay dalam penelitian ini lebih panjang dari berbagai penelitian sebelumnya, seperti yang dikutip oleh Halim (1999) yakni: Ashton (1987) di Canada sebanyak 62.5 hari; Ashton (1989) di Canada sebanyak 55 hari; Garsombke (1981) di Amerika sebanyak 53 hari dan penelitian Courtis dan Gilling (1976) di New Zealand adalah 62 hari

\subsection{Pengujian Hipotesis dan Pembahasan}

Hipotesis pertama diuji dengan menggunakan One way ANOVA yang hasil pengujian dapat dibaca pada tabel 5.

Tabel 5

Hasil Pengujian Hipotesis Pertama

\begin{tabular}{lcrrrr}
\hline & $\begin{array}{c}\text { Sum of } \\
\text { Squares }\end{array}$ & Df & Mean Square & F & Sig. \\
\hline Between Groups & 4646.608 & 2 & 2323.304 & 5.020 & .008 \\
Within Groups & 49979.500 & 108 & 462.773 & & \\
Total & 54626.108 & 110 & & & \\
\hline
\end{tabular}

Pada tabel 5 dapat dibaca bahwa hipotesis pertama didukung, tingkat signifikansi $p$-value sebesar 0,008 dengan nilai $\mathrm{F}$ sebesar 5,02. Artinya ada perbedaan audit delay ditinjau dari total revenue. Pada penelitian Ashton (1987) di Kanada, Courtis (1976) di New Zealand, Davies dan Whitterd di Australia (1980) (dalam Halim, 1999) menunjukkan bahwa audit delay mempunyai hubungan negatif dengan ukuran perusahaan dengan indikator yang digunakan adalah total revenue. Dengan demikian semakin tinggi total revenue perusahaan maka semakin pendek perusahaan menerbitkan laporan keuangan.

Tabel 6

Komparasi Rata-rata Audit Delay dari Total Revenue

\begin{tabular}{cccc}
\hline Kelompok total revenue & $\mathbf{N}$ & Rata-rata audit delay (hari) & Std Deviation \\
\hline Rendah & 102 & 73.16 & 21.76 \\
Sedang & 3 & 35 & 1 \\
Tinggi & 6 & 63.67 & 20.80 \\
Total & 111 & 71.62 & 22.28 \\
\hline
\end{tabular}


Pada tabel 6 dapat dibaca bahwa perusahaan-perusahaan keuangan yang memiliki total revenue kategori sedang memiliki audit delay paling cepat dibandingkan dengan perusahaan-perusahaan keuangan dengan total revenue yang tinggi maupun perusahaan-perusahaan keuangan yang total revenue rendah. Rata-rata audit delay untuk perusahaan dengan total revenue sedang adalah 35 hari sedangkan audit delay untuk perusahaan dengan total revenue tinggi dan perusahaan dengan total revenue adalah sebesar 63,67 hari dan 73,17 hari.

Perusahaan-perusahaan keuangan dengan total revenue sedang dan perusahaan-perusahaan keuangan yang mempunyai total revenue tinggi dianggap mempunyai sistem pengendalian internal yang baik sehingga dapat mengurangi tingkat kesalahan dalam penyajian laporan keuangan perusahaan. Ini dapat juga memudahkan auditor dalam melaksanakan pengauditan laporan keuangan dan perusahaan yang cenderung mendapatkan tekanan dari pihak eksternal terhadap kinerja perusahaan, sehingga manajemen akan berusaha untuk mempublikasikan laporan audit dan laporan keuangan lebih tepat waktu.

Hipotesis kedua diuji dengan menggunakan independent $t$-test yang hasilnya dapat dibaca pada tabel 7 berikut:

Tabel 7

Hasil Pengujian Hipotesis Kedua

t-test for Equity of Means

\begin{tabular}{lcccc} 
& $\mathbf{t}$ & Df & Sig. (2-tailed) & $\begin{array}{c}\text { Mean } \\
\text { Difference }\end{array}$ \\
\hline $\begin{array}{l}\text { Equal Variences Assumed } \\
\begin{array}{l}\text { Equal Variences not as- } \\
\text { sumed }\end{array}\end{array}$ & .398 & 109 & .692 & 1.70046 \\
\hline
\end{tabular}

Pada tabel 7 dapat dibaca bahwa hipotesis kedua tidak didukung. Ini berarti bahwa tidak ada perbedaan audit delay ditinjau dari aspek debt to total asset. Dalam penelitian ini, memberikan hasil yang berbeda dari penelitian sebelumnya yang dilakukan oleh Carslaw dan Kaplan (1989 dalam Yuliana dan Ardiati, 2004) yang menemukan bawah pada perusahaan yang mempunyai rasio debt to assets yang tinggi, perusahaan akan cenderung untuk memundurkan laporan keuangan. Debt to assets ratio mengindikasi kesehatan perusahaan, semakin tinggi debt to assets ratio mengindikasi perusahaan dalam kesulitan keuangan. Perusahaan akan mengurangi resiko dengan memundurkan publikasi laporan keuangannya dan mengulur waktu dalam pekerjaan auditnya.

Tabel 8

Komparasi Rata-rata Audit Delay ditinjau dari Debt to Asset Ratio

\begin{tabular}{lrrrr}
\hline Debt to Assets Ratio & N & Mean & $\begin{array}{c}\text { Std. } \\
\text { Deviation }\end{array}$ & Std. Error Mean \\
\hline Tinggi $(0,76$ s/d 1,47) & 49 & 72.57 & 16.62 & 2.37 \\
Rendah $(0,04$ s/d 0,76) & 62 & 70.87 & 26.06 & 3.30 \\
\hline
\end{tabular}

Dalam penelitian ini, debt to assets ratio dikategorikan menjadi dua yakni tinggi $(0,76 \mathrm{~s} / \mathrm{d} 1,47)$ dan rendah $(0,04 \mathrm{~s} / \mathrm{d}$ 0,76). Hasil yang didapat dari pengujian ini adalah tidak ada perbedaan audit delay ditinjau dari debt to assets ratio. Pada tabel 8 rata-rata audit delay Debt to assets ratio rendah adalah 70,87 hari dengan standar deviasi 26,06 hari sedangkan untuk Debt to Assets Ratio tinggi adalah 72,57 hari dengan standar deviasi 16,62 hari. Selisih audit delay hanya kurang lebih 2 hari dengan selisih deviasi standar 10 hari untuk kedua kelompok perusahaan yang digolongkan menurut tinggi-rendahnya debt to asset ratio. Dari hasil uji independent $t$-test (lihat tabel 7), perbedaan ini tidak signifikan sehingga tidak ada perbedaan audit delay ditinjau dari aspek Debt to Assets 
Ratio, meskipun audit delay untuk perusahaan dengan debt to assets ratio tinggi lebih panjang dibandingkan dengan perusahaan yang debt to assets ratio rendah.

Pengujian hipotesis ketiga menggunakan alat uji independent t-test yang hasilnya dapat dibaca pada tabel 9

Tabel 9

Hasil Pengujian Hipotesis Ketiga

\begin{tabular}{lcccc}
\hline & \multicolumn{4}{c}{ t-test for Equity of Means } \\
\cline { 2 - 5 } & $\mathbf{T}$ & df & Sig. (2-tailed) & $\begin{array}{c}\text { Mean } \\
\text { Difference }\end{array}$ \\
\cline { 2 - 5 } & -2.954 & 109 & .004 & -16.77034 \\
$\begin{array}{l}\text { Equal Variences assumed } \\
\text { Equal Variences not as- } \\
\text { sumed }\end{array}$ & -2.376 & 19.195 & .028 & -16.77034 \\
\hline
\end{tabular}

Dari tabel 9 dapat dibaca hipotesis ketiga didukung, yang berarti ada perbedaan audit delay ditinjau dari pengumuman rugi/laba.

Tabel 10

Komparasi Rata-rata Audit Delay dari Pengumuman Laba/rugi

\begin{tabular}{ccccc}
\hline Rugi / Laba & N & Mean & Std. Deviation & Std. Error Mean \\
\hline Laba & 94 & 69.05 & 20.27 & 2.09 \\
Rugi & 17 & 85.82 & 27.79 & 6.74 \\
\hline
\end{tabular}

Pada tabel 10, dapat dibaca bahwa rata-rata audit delay untuk perusahaan-perusahaan keuangan yang menyatakan rugi rata-rata audit delay selama 85,82 hari dengan standar deviasi 27,79 hari. Sedangkan perusahaan-perusahaan keuangan yang menyatakan pengumuman laba rata-rata audit delay selama 69,05 hari dengan deviasi standar 20,27 hari. Perbedaan audit delay untuk perusahaan-perusahaan keuangan yang mengumumkan rugi dan perusahaan-perusahaan keuangan yang mengumumkan laba adalah selama 16 hari dengan selisih standar deviasi 7,5 hari. Penelitian ini mendukung penelitian Asthon (1987) dan penelitian Carslaw (1991 dalam Halim, 1999). Pada perusahaan-perusahaan yang mengumumkan rugi cenderung akan menunda untuk mengumumkan "bad news" kepada publik. Auditor juga akan bertindak hati-hati selama proses audit dalam memberikan jawaban apakah peningkatan kerugian yang dialami oleh perusahaan diakibatkan oleh kegagalan manajemen. Perusahaan yang mengumumkan rugi maka audit delay perusahaan tersebut akan lebih panjang. Perusahaan yang mengumumkan laba, rata-rata audit delay adalah 69,05 hari dengan standar deviasi 20,27 hari. Perusahaan yang mengumumkan laba akan memberikan sinyal positif kepada pasar bahwa ada peningkatan kinerja manajemen perusahaan tersebut.

Pada pengujian hipotesis keempat diuji dengan independent $t$-test, yang hasilnya dapat dibaca pada tabel 11 
Tabel 11

Hasil Pengujian Hipotesis Keempat

\begin{tabular}{lcccc}
\hline & \multicolumn{5}{c}{ t-test for Equity of Means } \\
& T & df & Sig. (2-tailed) & $\begin{array}{c}\text { Means } \\
\text { Difference }\end{array}$ \\
\hline $\begin{array}{l}\text { Equal Variences assumed } \\
\begin{array}{l}\text { Equal Variences not as- } \\
\text { sumed }\end{array}\end{array} 1^{1.017}$ & 109 & .311 & 4.33114 \\
\hline
\end{tabular}

Dari tabel 11 dapat dibaca bahwa tidak hipotesis keempat tidak didukung. Ini berarti bahwa tdaik terdapat perbedaan antara perusahaan-perusahaan keuangan yang diaudit oleh KAP the big Four dengan KAP non the Big Four.

Penelitian sebelumnya yang dilakukan oleh Gilling (1977) dalam Hossain dan Taylor (1998) menguji secara empiris menemukan hubungan antara karakteristik perusahaan akuntan publik dan audit delay. Berdasarkan literatur yang ada cenderung mendukung bahwa KAP besar (the Big Four) lebih cepat menyelesaikan tugas audit yang mereka terima dibandingkan dengan KAP non Big Four, dikarenakan reputasi yang harus mereka jaga. KAP Big Four lebih efektif dan efisien dalam menyelesaikan tugas audit karena mereka mempunyai sumber daya (fasilitas, kompetensi dan keahlian auditor, dll) yang lebih besar dibandingkan dengan KAP non Big Four.

Tabel 12

Komparasi Rata-rata Audit Delay dari Karakteristik KAP

\begin{tabular}{ccccc}
\hline Karakteristik KAP & N & Mean & $\begin{array}{c}\text { Std. Devia- } \\
\text { tion }\end{array}$ & $\begin{array}{c}\text { Std. Error } \\
\text { Mean }\end{array}$ \\
\hline Non Big Four & 49 & 74.04 & 20.57 & 2.94 \\
Big Four & 62 & 69.71 & 23.54 & 2.99 \\
\hline
\end{tabular}

Hasil penelitian ini berbeda dengan penelitian sebelumnya yang dilakukan oleh Gilling (1977), Halim (1999), dan Yuliana dan Ardiati (2004). Studi ini menunjukkan bahwa tidak ada perbedaan audit delay ditinjau dari karakteristik KAP kelompok thd Big Four maupun kelompok non the Big Four.

Pada tabel 12, rata-rata audit delay untuk laporan keuangan yang diaudit oleh KAP Big Four adalah 69,71 hari dengan standar deviasi 23,54 hari sedangkan untuk audit delay untuk laporan keuangan yang diaudit oleh KAP non Big Four adalah 74,04 hari dengan standar deviasi 20,57 hari. Meskipun waktu audit yang digunakan oleh KAP the Big Four yang ditunjukkan dengan waktu audit delay lebih cepat dibandingkan dengan KAP non the Big Four, namun secara statistik tidak ada perbedaan signifikan. KAP Big Four lebih cepat menyelesaikan tugas audit, dikarenakan bahwa mereka harus menjaga reputasi. KAP the Big Four umumnya memiliki sumber daya yang lebih besar dibandingkan dengan KAP non Big Four sehingga mereka dapat menyelesaikan pekerjaan auditnya relatif lebih efektif dan efisien. Namun demikian, dengan adanya semakin ketatnya persaingan dalam lingkungan KA, maka KAP non theBig Four berusaha untuk mengaudit laporan keuangan klien dengan efektif dan efisien yang ditunjukkan bahwa selisih audit delay yang terjadi hanya selama 5 hari dengan selisih standar deviasi 3 hari. KAP non Big Four berusaha untuk memberikan jasa audit kepada kliennya dengan kualitas yang sama baiknya dengan KAP the Big Four.

\section{PENUTUP}

Ada 4 hipotesis dalam penelitian ini yang diuji dengan menggunakan independent t-test dan anova. Hipotesis pertama tentang ada perbedaan audit delay ditinjau dari total revenue dan hipotesis ketiga tentang ada perbedaan 
audit delay ditinjau dari aspek rugi/laba dapat didukung dalam penelitian ini. Sedangkan hipotesis kedua tentang ada perbedaan audit delay ditinjau dari Debt to Assets Ratio dan hipotesis keempat tentang ada perbedaan audit delay ditinjau dari laporan keuangan yang diaudit oleh KAP Big Four dan KAP non Big Four tidak dapat didukung dalam penelitian ini.

Penulis menyadari adanya keterbatasan dalam penelitian ini, antara lain: pertama, banyaknya perusahaan keuangan yang harus dikeluarkan dari sampel disebabkan oleh ketidaklengkapan data dari perusahaan tersebut, sehingga dapat menyebabkan hasil tidak dapat digeneralisasi. Kedua, jumlah tahun pengamatan yang singkat, yaitu dari tahun 2002 sampai dengan 2004 juga dapat menyebabkan hasil penelitian ini kurang maksimal.

Implikasi dari hasil penelitian ini ada dua yakni secara praktis dan teoritis. Bagi para investor, hasil penelitian ini dapat dipertimbangkan dalam pengambilan keputusan investasi. Para investor tidak perlu ragu apabila laporan keuangan perusahaan diaudit oleh KAP non Big Four sebab tidak ada perbedaan audit delay ditinjau dari laporan keuangan yang diaudit oleh Kantor Akuntan Publik Big Four maupun laporan keuangan yang diaudit oleh Kantor Akuntan Publik non Big Four. Implikasi secara teoritis, hasil penelitian ini dapat menambah literatur penelitian audit delay yang ditinjau dari aspek keuangan (contoh variabel total revenue dan debt to asset ratio) maupun aspek auditor (audit opinion) dan karakteristik KAP (the Big Four - nno the Big Four) yang berdampak pada lamapendeknya audit delay.

Pada penelitian dimasa mendatang, para peneliti dapat menggunakan lebih banyak variasi varibel keuangan maupun variabel non keuangan yang dapat digunakan untuk menguji audit delay. Selain itu penelitian lain serupa dapat dilakukan untuk mengkonfirmasi hasil penelitian ini dengan menggunakan pendekatan yang sama yakni uji beda.

\section{DAFTAR PUSTAKA}

Abdulla, J.Y.A., (1996), "The Timeliness of Bahzaini Annual Reports”, Advances in Internal Accounting., Vol. 9.

Ashton, R.H., Willingham, JJ., dan elliot, R.K., (1987), "An Empirical Analysis of Audit Delay”, Journal of Accounting Reserach, Vol.25., No.2

Carslaw, C.A.P.N., dan Kaplan, S.E., (1991), "An Examination of Audit Delay: Further Evidence from New Zealand", Accounting and Business Reserach, Vol.22., No.85

Dyewr, J.C dan McHugh, A.J., (1975), "The Timelieness of Australian Annual Report", Journal of Accounting Research, Autumn

Givoly, D., dan Palmon, D., (1982), "Timeliness of Annual Earning Announcements: Some Empirical Evidence”, The Accounting Review, Vol.LVII., No,3

Halim, Verinada, (1999), "Faktor-faktor yang Mempengaruhi Audit Delay, Jurnal Bisnis dan Akuntansi, Vol.2.

Hossain, M.A dan P.J.Taylor, (1998), "An Examination of Audit Delay: Evidence from Pakistan, Working Paper, unpublised.

Imam, Shahed, Z.U Ahmed, dan S.H Kahn., (2001), "Association of Audit Delay and Audit Firms' International Links: Evidence from Bangladesh", Managerial Auditing Journal, Vol.16., No.3

Lawence, Janice dan B. Bryan, (1998), "Characteristis Associated with Aduti Delay in the Monitoring of Low Income Housing Projects", Journal of Public Budgeting, Accounting \& Financial Management, Vol.10, No.2

Na'im, A., (1998), "Timeliness of Annual Financial Statement Submission: A Preliminary Empirical Evidence from Indonesia, theses, unplished. 
Owusu-Ansah, S., (2000), "Timeliness of Corporate Financial Reporting in Emerging Capital Markets: Empirical Evedience from Zimbabwe Stock Exchange", Accounting and Business Research, Summer.

Wirakusuma, Made Gedhe, (2004), "Faktor-faktoryang Mempengaruhi Rentang Waktu Penyajian Laporan Keuangan ke Publik (Studi empriris Mengenai Keradaan Divisi Internal Audit pada Persuaahaan-perusahaan yang Terdaftar di Bursa Efek Jakarta", SNA VII Denpasar Bali.

Yuliana dan A.Y. Ardiati, (2004), "Faktor-faktor yang Mempengaruhi Audit Delay di Indonesia", Modus Vol.16., No.2 